\title{
Further new or interesting lichens and lichenicolous fungi from La Palma (Canary Islands, Spain)
}

\author{
Pieter P. G. van den Boom ${ }^{1} \&$ Philippe Clerc ${ }^{2}$ \\ ${ }^{1}$ Arafura 16, NL-5691 JA Son, the Netherlands. E-mail: pvdboom@kpnmail.nl \\ ${ }^{2}$ Conservatoire et Jardin botaniques de la ville de Genève, Chemin de l'Impératrice 1, Case postale 60, CH-1292 Cham- \\ bésy, Switzerland. E-mail: Philippe.Clerc@ville-ge.ch
}

\begin{abstract}
Forty-five taxa of lichens and lichenicolous fungi are recorded from La Palma for the first time. Twelve are new to the Canary Islands archipelago. One further species, Didymocyrtis canarienis, is described as new for science. The total number of known taxa from the island La Palma has raised to 874. An alphabetical annotated species list of all taxa with collection localities, substrate and occasional further annotations is presented.
\end{abstract}

Keywords: Ascomycetes; biodiversity; distribution; substrata; taxonomy; mycobiota of Macaronesia

\section{INTRODUCTION}

Together with El Hierro, La Palma is the most western island of the Canary Island archipelago (Fig. 1). The lichens and lichenicolous fungi of La Palma have received considerable attention in recent years. For a survey of literature see Hernández-Padrón \& Pérez-Vargas (2010), with 752 records, and Van den Boom (2007), in which 47 additional species are recorded from La Palma. A record of Tephromela folmanii PérezVargas, Hern.-Padr. \& Elix was published by Pérez-Vargas et al. (2010a), Usnea chaetophora Stirt. by Pérez-Vargas et al. (2010c), Vahliella isidioidea Pérez-Vargas, C. Hdez.-Padr., van den Boom \& P. M. Jørg., from La Palma was added by Pérez-Vargas et al. (2014), Diploschistes albopruinosus Pérez-Vargas, C. Hdez.-Padr. \& Elix was described by Pérez-Vargas et al. (2012b), Pérez-Vargas et al. (2015a) described Caloplaca nigrocarpa Pérez-Vargas \& C. Hdez.-Padr., Pérez-
Vargas et al. (2015b) record 7 new Cladonia species, and 17 additional Buellia s. 1. records have been found in Giralt \& Van den Boom (2011), making a total of 828 species.

Here we bring results from fieldwork by the first author and his wife mainly in the eastern part of the island, in autumn of 2012 (for the locality list see below). The material of the genus Usnea was subjected to a detailed study by one of us (PC), who checked many specimens of which five are new records for the island. Totally fortyfive taxa are recorded for the first time for the island. Twelve species are unrecorded for the Canary Islands archipelago before. One further species, Didymocyrtis canarienis van den Boom $\&$ Etayo, is described as new for science. They all are presented here. The study of our material revealed 46 additional new taxa for the island, raising the total number to 874 .

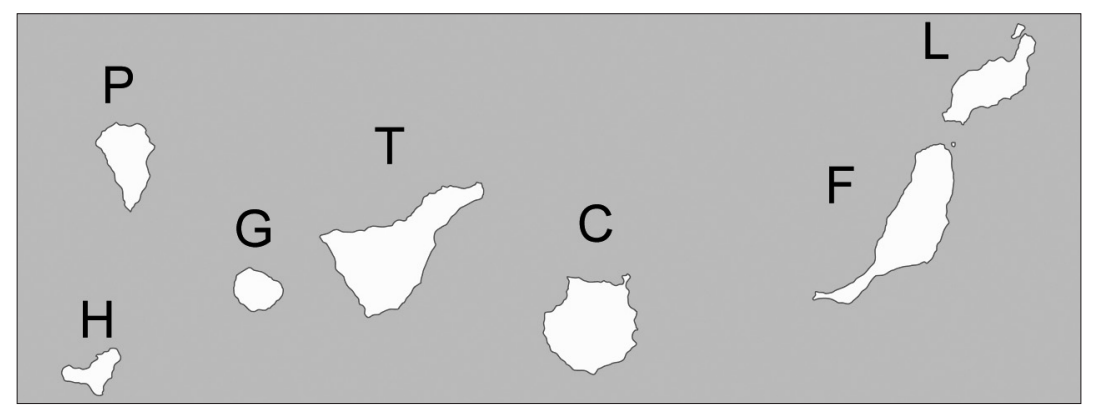

Fig. 1. Schematic map of the Canary Islands with the situation of La Palma (P). The other islands are: Gran Canaria (C), Fuerteventura (F), El Hierro (H), La Gomera (G), Lanzarote (L) and Tenerife (T). 


\section{MATERIALS AND METHODS}

More than 500 specimens of lichens and lichenicolous fungi were examined, collected by the first author and his wife on volcanic rock, on soil and on trees and shrubs, in 15 localities, mainly in the eastern part of the island La Palma. To establish whether a record is new for La Palma or the Canary Islands, the most recent checklist for lichens and lichenicolous fungi of the Canary Islands, Hernández-Padrón \& Pérez-Vargas (2010), was consulted and indicated as H-2010 below. The following more recent publications were also checked: Aptroot \& Schumm (2012), van den Boom (2010, 2013), van den Boom \& Clerc (2015), van den Boom \& Ertz (2012), van den Boom \& Etayo (2017), van den Boom et al. (2015), Giralt \& van den Boom (2011), Montelongo et al. (2015), Pérez-Vargas \& Pérez-Ortega (2014), Pérez-Vargas et al. (2010b, 2010d, 2011, 2012a, 2012b, 2013, 2014, 2015a, 2015b) and Tehler et al. (2013).

Chemical constituents were identified by the standard methods of thin-layer chromatography (TLC) according to Orange et al. (2010). Some specimens were checked by specialists, as noted under the pertinent species. The indicated voucher specimens are kept in the private herbarium of P. van den Boom (herbarium numbers between 48300 and 49000), the type specimen and duplicates of all specimens mentioned below are kept in TFC.

\section{Sampling localities on La Palma}

$1-3.5 \mathrm{~km}$ WSW of Los Sauces, Los Tilos, laurisilva, narrow cleft with path along $\mathrm{N}$ facing volcanic outcrops, between tunnel and Mirador, $28^{\circ} 47.10^{\prime} \mathrm{N}, 17^{\circ} 48.60^{\circ} \mathrm{W}, 750 \mathrm{~m}, 27$ October 2012.

2 - Mazo, shop of Ceramics 'El Molino' and small botanical garden, on stones of wall and wood of roof, $28^{\circ} 36.60^{\prime} \mathrm{N}, 17^{\circ} 46.40^{\prime} \mathrm{W}, 335 \mathrm{~m}, 28$ October 2012.

3 - SW of Breña Alta, SW of San Isidro, N side of road LP203/LP301, trail Camino de la Cumbre (PR LP18.2), to El Llanito, small forest with Erica, Laurus and Myrica and small orchard with Juglans, $28^{\circ} 38.00^{\prime} \mathrm{N}$, $17^{\circ} 48.50 ` \mathrm{~W}, 760 \mathrm{~m}, 28$ October 2012.

4 - SW of Breña Alta, SW of San Isidro, along road LP203/LP301, between Pared Vieja and El Pilar (halfway), just a few meters in for- est with Erica, Laurus and Myrica a ruderal place with bones on the ground, $28^{\circ} 37.00^{\prime} \mathrm{N}$, $17^{\circ} 49.30^{\prime} \mathrm{W}, 1170 \mathrm{~m}, 28$ October 2012.

5 - SW of Breña Alta, SW of San Isidro, along road LP203/LP301, between Pared Vieja and El Pilar, near house, few hundred meters west of crossing, at roadside, rim of forest with mainly Erica and Laurus, including some terricolous lichens, $28^{\circ} 36.80^{\prime} \mathrm{N}$, $17^{\circ} 49.20^{\prime} \mathrm{W}, 1410 \mathrm{~m}, 28$ October 2012.

6 - SW of Breña Alta, SW of San Isidro, near road LP203/LP301, $1 \mathrm{~km}$ west of El Pilar, trail LP17, started near barn, open forest with mature Pinus trees and small Erica shrubs, $28^{\circ} 36.60^{\prime} \mathrm{N}, 17^{\circ} 49.70^{\prime} \mathrm{W}, 1440 \mathrm{~m}$, 28 October 2012.

$7-3.5 \mathrm{~km}$ WSW of Los Sauces, Los Tilos, laurisilva, steep trail from visitors centre to mirador de las Barandas, poor in macro lichens, $28^{\circ} 47.70^{\prime} \mathrm{N}, 17^{\circ} 47.90^{\prime} \mathrm{W}, 750 \mathrm{~m}, 29$ October 2012.

$8-3.5 \mathrm{~km}$ WSW of Los Sauces, Los Tilos, laurisilva, trail from mirador de las Barandas, to Laguna de Barlovento, first $100 \mathrm{~m}$, with ruderal places, poor in macro lichens, $28^{\circ} 47.80^{\prime} \mathrm{N}, 17^{\circ} 47.95^{\prime} \mathrm{W}, 755 \mathrm{~m}, 29$ October 2012.

9 - SW of Los Sauces, W of Lomadas, trail from Los Cancelas (LP6) to (direction of) Casa del Monte, with mostly ruderal places, mainly in 'fayal brezal', many young trees, some Laurus and Ilex, poor in macro lichens, $28^{\circ} 47.26^{\prime} \mathrm{N}, 17^{\circ} 47.35^{\prime} \mathrm{W}, 700 \mathrm{~m}, 29$ October 2012.

10 - W of La Galga, Cubo de La Galga, laurisilva in big valley with shaded steep volcanic outcrops, $28^{\circ} 45.60^{\prime} \mathrm{N}, 17^{\circ} 47.00^{\circ} \mathrm{W}, 650 \mathrm{~m}$, 31 October 2012.

11 - SW of Breña Alta, SW of San Isidro, N side of road LP203/LP301, 'Pared Vieja' picnic place, open area with a few mature Pinus trees and trail in open forestry area with stumps, Erica, Laurus and Myrica, $28^{\circ} 37.10^{\prime} \mathrm{N}, 17^{\circ} 49.70^{\prime} \mathrm{W}, 1260 \mathrm{~m}, 1$ November 2012 .

12 - SW of Breña Alta, SW of San Isidro, N side of road LP203/LP301, E of Refugio El Pilar, near pole of brick with chain as a fence, trail in forest with mature Pinus trees, $28^{\circ} 36.60^{\prime} \mathrm{N}, 17^{\circ} 49.90^{\circ} \mathrm{W}, 1450 \mathrm{~m}, 1$ November 2012.

13 - SW of Breña Alta, SW of San Isidro, S road LP203/LP301, opposite mirador 'observa- 
toric', trail in forest with Erica, Laurus and Myrica, $28^{\circ} 36.80^{\prime} \mathrm{N}, 17^{\circ} 49.40^{\prime} \mathrm{W}, 1330 \mathrm{~m}, 1$ November 2012.

14 - SW of Breña Alta, SW of San Isidro, S of Pared Vieja, S side of road LP203/LP301, small trail in forest with Erica, Laurus, Myrica and rich in terricolous lichens, $28^{\circ} 36.60^{\prime} \mathrm{N}, 17^{\circ} 49.30^{\prime} \mathrm{W}, 1245 \mathrm{~m}, 1$ November 2012 .

15 - SW of Breña Alta, $2.8 \mathrm{~km}$ SW of San Isidro, N side of road LP203/LP301, some mature Pinus trees with many broken branches, $28^{\circ} 37.60^{\prime} \mathrm{N}, 17^{\circ} 48.60^{\prime} \mathrm{W}, 900 \mathrm{~m}, 1$ November 2012 .

\section{RESULTS}

\section{New species}

\section{Didymocyrtis canariensis van den Boom \& Etayo sp. nov. (Fig. 2)}

MycoBank no.: MB 822253

Diagnosis: Species lichenicolous on Ramalina subgeniculata; perithecia immersed, dark brown to black, subglobose to globose, up to $250 \mu \mathrm{m}$ diam.; ascomatal wall 10-15 $\mu \mathrm{m}$ thick; asci cylindrical to slightly clavate, 75-95 × 7-9 $\mu \mathrm{m}$; ascospores obliquely monostichous in the asci, ellipsoid, fine warted, brown, 1-septate, 9-11(-12) × 4.5-5.5 $\mu \mathrm{m}$. Conidiomata immersed, black, subspherical 100-150 $\mu \mathrm{m}$ diam., wall dark brown, 2-3 layers of cells, cells angular up to 8-10 $\mu \mathrm{m}$ wide; conidia broadly ellipsoid to slightly ovoid, subspherical, with one large guttule, 4.5-5.5 × 3.5-4 $\mu \mathrm{m}$.

Type: SPAIN, Canary Islands, La Palma, $\mathrm{N}$ of Santa Cruz, W of La Galga, Cubo de La Galga, laurisilva, in a big valley with shaded steep volcanic outcrops, on fallen Castanea tree, $28^{\circ} 45.6^{\prime} \mathrm{N}, 17^{\circ} 47.0^{\prime} \mathrm{W}, 650 \mathrm{~m}, 31$ October 2012, P. \& B. van den Boom 48685 (TFC, holotype; hb. van den Boom, hb. Etayo, isotype).

Description: Ascomata lichenicolous, perithecioid, scattered, subglobose to globose, sometimes flattened, immersed, with visible ostiole, in section up to $250 \mu \mathrm{m}$ in diam.; ascomatal wall pale to medium brown, consisting of about 3-6 layers of cells, c. 10-15 $\mu \mathrm{m}$ thick, composed of angular cells, cells up to $12 \mu \mathrm{m}$ wide; hamathecial filaments present at maturity, sometimes branched and anastomosing, 1-1.5(-2) $\mu \mathrm{m}$ thick, hymenial gelatine I-; asci narrowly cylindrical to slightly clavate, apically thickened when mature, with a small ocular chamber, ascal wall I- and KI- in all parts, 8-spored, 75-95 × 7-9 $\mu \mathrm{m}$; ascospores obliquely monostichous in the asci, sometimes slightly overlapping, ellipsoid, mostly constricted at the septum, when young hyaline to pale brown without a perispore, soon dark brown, fine warted when mature, 1-septate, septum sometimes formed towards
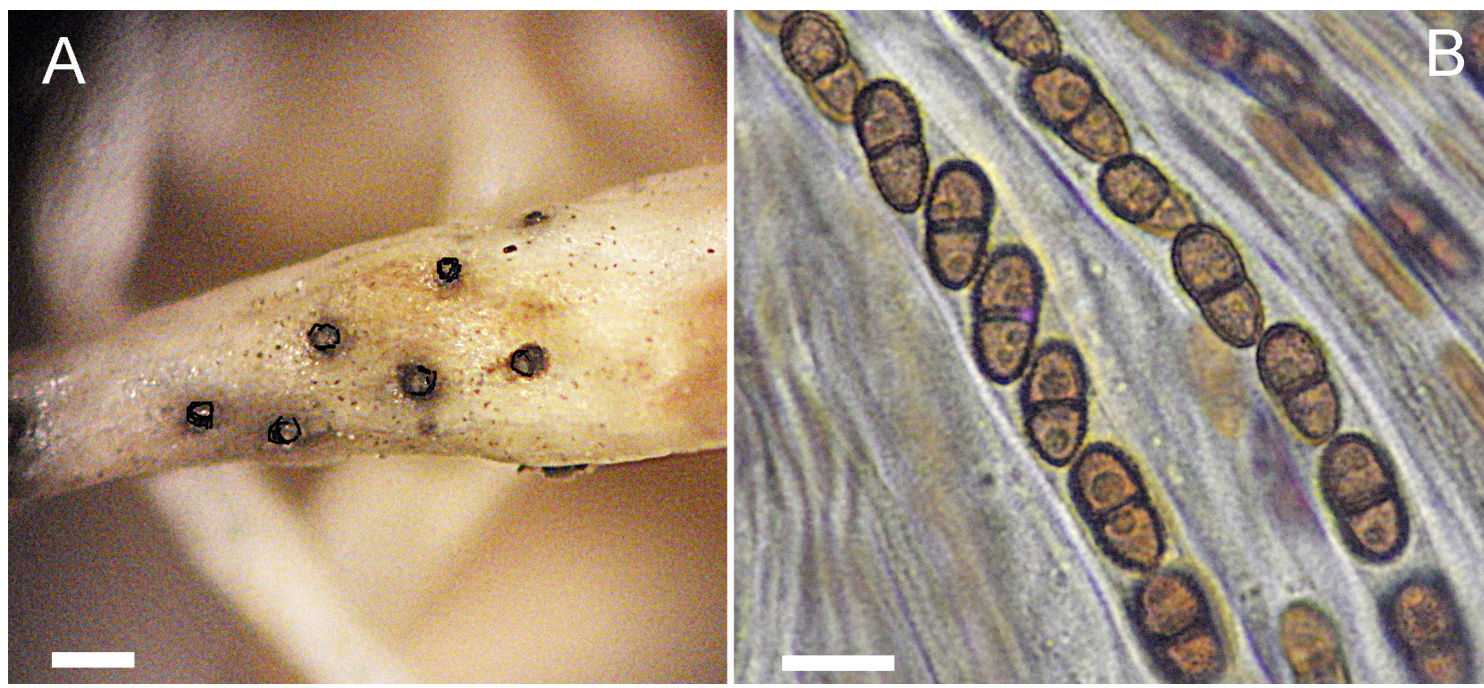

Fig. 2. Holotype (TFC Lich 16041). A - habitus, perithecia in thallus of Ramalina. B - ascospores in ascus. Scale: A - $0.2 \mathrm{~mm} ; \mathrm{B}-10 \mu \mathrm{m}$. 
the lower end of the ascospores, 9-11(-12) $\times$ 4.5-5.5 $\mu \mathrm{m}$; conidiomata immersed, black, subspherical, 100-150 $\mu \mathrm{m}$ diam., wall dark brown, 2-3 layers of cells, cells angular, up to 8-10 $\mu \mathrm{m}$ wide; conidia broadly ellipsoid to slightly ovoid, subspherical, with one large guttule, 4.5-5.5 $\times$ 3.5-4.5 $\mu \mathrm{m}$.

Etymology: The epithet refers to the archipelago where the species occurs.

Distribution and ecology: So far, known from three islands of the Canary Islands archipelago, Gran Canaria, La Gomera and La Palma including the type locality, occurring on Ramalina subgeniculata, on bark of an fallen Castanea tree at $650 \mathrm{~m}$ altitude. It does most probably not damage the host; the colour of the host turns not or slightly paler. All the known collections are from the same host species, $R$. subgeniculata, or what has been mentioned as Ramalina sp. but these refer most probably also to $R$. subgeniculata. Other lichenicolous fungi, found close to the new species, are Lichenoconium erodens M.S. Christ. $\&$ D. Hawksw., Lichenopeltella ramalinae Etayo $\&$ Diederich and Tremella ramalinae Diederich, in specimens 49025, 22228 and 48562 (hb. van den Boom) respectively.

Notes: Most of the species of Didymocyrtis are recorded from macrolichens (Ertz et al., 2015) and following the identification key to species of Didymocyrtis in that study, the new species is most similar to D. infestans (Speg.) Hafellner, a species known to occur on Teloschistes and differing by larger ascomata (250-350 $\mu \mathrm{m}$ diam.), developing in the hymenium and/or thallus branches of the host, immersed, finally somewhat protruding. This latter character has never been observed in the new species. The new species has been found on thallus and apothecium margin of the host but never in the hymenium. Two species are known from crustose host lichens, Caloplaca and Lecanora. Didymocyrtis bryonthae (Arnold) Hafellner known from Lecanora epibryon, has ascomata often developing in the hymenium but also in thallus branches, immersed, finally somewhat protruding, it has somewhat longer ascospores, 11.5-14 × 4-5 $\mu \mathrm{m}$, but the ascomata are smaller, 150-200(-250) $\mu \mathrm{m}$ diam., immersed in apothecia that turns black and asci are shorter, 60-80 $\times$ 7-10 $\mu \mathrm{m}$. Didymocyrtis consimilis Vain., known from Caloplaca, has ascospores of 12-15 × 5-6 $\mu \mathrm{m}$, hardly constricted at the septum, with a verruculose sculpture hardly visible in light microscopy and the ascomata are much smaller than in the new species (70-)100-150 $\mu \mathrm{m}$ diam. Didymocyrtis ramalinae (Roberge ex Desm.) Ertz, Diederich \& Hafellner looks rather similar in habitus, but that species has 3-septate ascospores, 14-20 × 5-6.5 $\mu \mathrm{m}$, conidiomata immersed in pale necrotic areas of the thallus or apothecial margin surrounded by a black line, black, subspherical, 105-135 $\mu \mathrm{m}$ diam.; conidia ellipsoid, biguttulate, with a small guttule near each apex, 5-7 $\times 3-4 \mu \mathrm{m}$ and it is widely distributed in Europe and known from Africa and Australia (Ertz et al., 2015). A further similar species, Endococcus ramalinarius (Lindsay) D. Hawksw., has ascospores clearly constricted at the septum, 10-13 $\times 4-4.5 \mathrm{~m}$ and it is growing on Ramalina leidoea in New Zealand. Hawksworth (1979) lectotypified and discussed this species. Additional specimens examined: SPAIN, Canary Islands, La Palma, $3.5 \mathrm{~km}$ WSW of Los Sauces, Los Tilos, laurisilva, narrow cleft with path along steep N facing rock, between tunnel and Mirador, on unidentified tree, $28^{\circ} 47.5^{\prime} \mathrm{N}, 17^{\circ} 48.1^{\prime} \mathrm{W}, 700 \mathrm{~m}, 3$ May 1999 , P. \& B. van den Boom 22228 (hb. v.d. Boom); SW of Los Sauces, W of Lomadas, trail from Los Cancelas (LP6) to (direction of) Casa del Monte, with mostly ruderal places, mainly in 'fayal brezal', many young trees, some Laurus and Ilex, 28 47.26'N, $17^{\circ} 47.35^{\prime} \mathrm{W}$, 700 m, 29 October 2012, P. \& B. van den Boom 48562 (hb. v.d. Boom); La Galga, Cubo de La Galga, on Ramalina sp. on Myrica faya, 13 August 1995, J. Etayo 14032 (hb. Etayo). Gran Canaria, SE of Gáldar, E of Moya, along road near El Palmital, fayal-brezal, N side of road with many Cladonia mediterranea and $\mathrm{S}$ side of the road with acidic outcrops, on Hypericum, $28^{\circ} 6.69^{\prime} \mathrm{N}, 15^{\circ} 36.2^{\prime} \mathrm{W}, 500 \mathrm{~m}, 8$ February 2013, P. \& B. van den Boom 49025 (hb. v.d. Boom). La Gomera, riscos encima de Tagaluche, por pista Encherada, on unidentified shrub, 650 m, 22 July 2000, J. Etayo 17754 (hb. Etayo); road from San Sebastián to Hermigua, $2 \mathrm{~km}$ from the village, pinar, on Ramalina sp. on Pinus, 2 August 1994, J. Etayo 13839 (hb. Etayo).

\section{Annotated species list}

Species new to the Canary Islands are marked with *; the islands are abbreviated as follows: Gran Canaria (C), Fuerteventura (F), El Hierro $(\mathrm{H})$, La Gomera (G), Lanzarote (L), La Palma (P) and Tenerife (T).

*BACIDINA BRITTONIANA (Riddle) LaGreca \& Ekman - Loc. 1, on Ocotea, 48384, identified by S. Ekman.

BACIDIA VIRIDIFARINOSA Coppins \& P. James - Loc. 1 , on volcanic rock, $48347 ; 1$, on exposed roots, 48371 . The first specimen is fertile. 
Buellia stellulata (Taylor) Mudd - Loc. 2, on stone of wall, 48397. In Giralt \& van den Boom (2011) it is recorded from C, F, H, L and $\mathrm{T}$.

*Caloplaca asserigena (Lahm.) H. Oliver - Loc. 5 , on unidentified shrub, $48442 ; 14$, on unidentified shrub, 48780.

Catillaria usneicola Etayo - Loc. 15, on Pinus, 48814, on Usnea. Known from $\mathrm{G}$ and $\mathrm{H}$ (van den Boom \& Ertz, 2012).

*Cladonia conista Robbins ex A. Evans - Loc. 11, terricolous, 48724, identified by T. Ahti \& R. Pino. This species belongs to the Cladonia humilis complex, but our specimen contains protocetraric acid, fumarprotocetraric acid and bourgeanic acid.

Cladonia floerkeana (Fr.) Flörke - Loc. 6, on Pinus, 48495. Previously only known from El Hierro (van den Boom \& Ertz, 2012) and from Tenerife (Pérez-Vargas et al., 2015b).

Cladonia nana Vain. - Loc. 9, terricolous, 48536 , identified by T. Ahti \& S. Stenroos. This specimen contains protocetraric acid, fumarprotocetraric acid. In van den Boom \& Ertz (2012) this species is published as an uncertain record.

Cladonia POlydactyla (Flörke) Sprengel - Loc. 12, on Pinus, 48737, 48749; 6, on Pinus, 48492. Known from C (van den Boom \& Clerc, 2015) and from La Gomera (van den Boom et al., 2015).

Cliostomum GRIffithiI (Sm.) Coppins - Loc. 4, on Erica, 48426; 15, on Pinus, 48803; Only known from $H$ (van den Boom \& Ertz, 2012), where it is rather common.

EvERNIASTRUM SOROCHEILUM (Vain.) Hale \& Sipman - Loc. 5, on Erica, 48435.

GRAPHIS SCRIPTA (L.) Ach. - Loc. 1, on bark of fallen trunk, 48333.

HYPOTRACHYNA AFROREVOLUTA (Krog \& Swinscow) Krog \& Swinscow - Loc. 5, on unidentified shrub, 48450, known from $\mathrm{H}$ (van den Boom $\&$ Ertz, 2012) and from $G$ (van den Boom et al., 2015).

HYPOTRACHYNA ROCKII (Zahlbr.) Hale - Loc. 10, on bark of fallen branch, 48671.

*Koerberia BIformis A. Massal. - Loc. 9, on Ilex, 48540.

LAMBINONIA STRIGULAE (Elenkin \& Woronichin) Sérusiaux \& Diederich - Loc. 1, on leaf of Laurus, on Strigula, 48353; 10, on leaf of Ocotea, on Strigula, 48644.

LeCANia NAEgeli (Hepp) Diederich \& van den Boom - Loc. 9, on Ilex, 48556.
*Lecanora Farinaria Borrer - Loc. 12, on Pinus branch, 48742; 14, on unidentified shrub, 48779, 48796, identified by T. Tønsberg.

LECANORA STROBILINA (Spreng.) Kieff. - Loc. 15, on branch of Pinus, 48804.

*Lecanora subsaligna Brand \& van den Boom Loc. 14, on unidentified shrub, 48798.

LECIDEA ERYTHROPHAEA Flörke - Loc. 9, on Ilex, 48554, known from $\mathrm{G}$ (H-2010).

Lecidella EupHorea (Flörke) Hertel - Loc. 3, on Juglans, 48414.

LEPRARIA FINKII (B. de Lesd.) R. C. Harris - Loc. 13 , on sloping soil, $48766 ; 4.5 \mathrm{~km}$ WSW of Los sauces, Los Tilos, laurisilva, narrow cleft over Barranco del Agua, on Erica arborea, 800 m, 3 May 1999, P. \& B van den Boom 22296, identified by T. Tønsberg.

LEPRARIA UMBRICOLA Tønsberg - Loc. 3, on exposed roots, 48402; 7, on Myrica faya, 48512; on overhanging base of Laurus, 48581, identified by T. Tønsberg. Recently recorded as new to the Canary Islands (La Gomera) by van den Boom et al. (2015).

*Leptogium Coralloideum (Meyen \& Flot.) Vain. - Loc. 10, on bark of fallen branch, 48641.

*Malmidea fuscella (Müll. Arg.) Kalb \& Lücking - Loc. 1, on unidentified tree, 48312, 48342; 1 , on fallen tree, 48338, identified by $\mathrm{R}$. Lücking. Portugal, Madeira, NE of Funchal, $\mathrm{W}$ of Portela, trail to the west, along levada, in laurisilva area with mature Acer trees along the trail, $32^{\circ} 44.68^{\prime} \mathrm{N}, 16^{\circ} 49.92^{\prime} \mathrm{W}$, $665 \mathrm{~m}, 28$ April 2012, on Laurus, 47690; NW of Funchal, road (ER228) from Ribeira Brava to São Vicente, c. $1 \mathrm{~km} \mathrm{~N}$ of Boca da Encumeada, trail PR22 'Vereda do Chao dos Louros', along laurisilva, 32 45.50' $\mathrm{N}, 17^{\circ} 1.10^{\prime} \mathrm{W}, 880 \mathrm{~m}, 30$ April 2012, on Laurus, 47798.

Micarea Peliocarpa (Anzi) Coppins \& R. Sant. Loc. 14, on unidentified shrub, 48790.

Pertusaria PUPILlaris (Nyl.) Th. Fr. - Loc. 12, on Pinus, 48748, identified by T. Tønsberg.

Pertusaria PUStUlata (Ach.) Duby - Loc. 10, on Castanea, 48686.

*PhaEophyscia endococcina (Körb.) Moberg - Loc. 7 , on acidic rock, 48500.

*RAmboldia subcinnabarina (Tønsberg) Kalb, Lumbsch \& Elix - Loc. 12, on fallen branch of Pinus, 48734, 48744. This species was previously only known from Norway, western USA and Canada (British Columbia), identified by T. Tønsberg. 
Rinodina BILOculata (Nyl.) Sheard - Loc. 14, on unidentified shrub, 48788, 48797. In $\mathrm{H}-2010$ it is recorded from $\mathrm{G}$.

*Scoliciosporum GalluRAe Vězda \& Poelt - Loc. 15, on branch of Pinus, 48818.

*Stigmidium Cladonilcola Zhurb. \& Diederich Loc. 11, on Pinus, 48703, on Cladonia sp.

THELOTREMA LAURISILVAE Lücking \& Breuss - Loc. 1 , on unidentified tree, 48329.

Topelia Rosea (Serv.) P. M. Jørg. \& Vězda - Loc. 1 , on volcanic rock, 48313.

Trapelia corticola Coppins \& P. James Loc. 4, on Erica, 48418; 11, on stump, 48725,48728 ; 13 , on wood, 48765 . Known from $\mathrm{G}$ and $\mathrm{T}$ (H-2010).

TRAPELIA GLEBUlOSA (Sm.) J. R. Laundon - Loc. 11, terricolous, 48717. Recorded as T. involuta from $\mathrm{G}$ and $\mathrm{T}$ (H-2010).

TRAPEliopsis PSEUdogranulosa Coppins \& P. James - Loc. 12, on Pinus, 48738, known from $\mathrm{G}$ and $\mathrm{T}$ (H-2010).

Tremella Ramalinae Diederich - Loc. 9, on Laurus, 48561, on Ramalina; 9, on Ilex, 48553, on Ramalina.

USNEA FLAVOCARDIA Räsänen - Loc. 5, on Erica, 48469, 48474, 48477, 48481, 48483, 48485; 15, on branch of Pinus, 48802. From $\mathrm{G}, \mathrm{H}$ and $\mathrm{T}$ recorded in $\mathrm{H}-2010$. From $\mathrm{C}$ it is recorded in van den Boom \& Clerc (2015).

USNEA FRAGILESCENS Lynge - Loc. 11, on branch of Pinus, 48684. Recorded from T (H-2010).

USNEA GEISSLERIANA P. Clerc - Loc. 11 , on mature Pinus, 48706. Recorded from $\mathrm{G}, \mathrm{H}$ and $\mathrm{T}$ (H-2010).

USNEA GLABRATA Vain. - Loc. 11, on branch of Pinus, 48689. Only recorded from $\mathrm{T}(\mathrm{H}-$ 2010).

USNEA MACARONESICA P. Clerc - Loc. 11, on branch of Pinus, 48684. Recorded from G, $\mathrm{H}$ and $\mathrm{T}$ (H-2010).

\section{ACKNOWLEDGEMENTS}

We would like to thank for identification/conformation Stefan Ekman (Bacidina), Robert Lücking (Malmidea), Tor Tønsberg (Lepraria, Pertusaria, Ramboldia), Ted Ahti, Raquel Pino, Soili Stenroos (Cladonia), and Jan Vondrák (Caloplaca). Special thanks are for Bern van den Boom as she did a lot of very useful fieldwork, to Javier Etayo for describing the new Didymocyrtis canarienis together with the first author, and to Harrie Sipman for correcting the final version of the manuscript.

\section{REFERENCES}

Aptroot, A. \& Schumm, F. 2012. A new terricolous Trapelia and a new Trapeliopsis (Trapeliaceae, Baeomycetales) from Macaronesia. Lichenologist 44(4): 449-456. https://doi.org/10.1017/ S0024282912000084

Boom, P. P. G. van den 2007. New and interesting lichenized and lichenicolous fungi from the Canary Island La Palma. Annalen des Naturhistorischen Museums in Wein 108B: 153-166.

Boom, P. P. G. van den 2010. Lichens and lichenicolous fungi from Lanzarote (Canary Islands), with the descriptions of two new species. Cryptogamie, Mycologie. 31(2): 183-199.

Boom, P. P. G. van den 2013. Further new or interesting lichens and lichenicolous fungi of Tenerife (Canary Islands, Spain). Stapfia 99: 52-60.

Boom, P. P. G. van den \& Ertz, D. 2012. Lichens and lichenicolous fungi from El Hierro (Canary Islands), a survey, including five new species. Cryptogamie, Mycologie. 33: 59-97. https://doi. org/10.7872/crym.v33.iss 1.2012.059

Boom, P. P. G. van den \& Clerc, P. 2015. Further new or interesting lichens and lichenicolous fungi from Gran Canaria (Canary Islands, Spain). Österreichische Zeitschrift für Pilzkunde. 24: 1-8.

Boom, P. P. G. van den \& Etayo, J. 2017. Further interesting lichens and lichenicolous fungi from Fuerteventura, Canary Islands (Spain), with three new species and notes on Mixtoconidium. Ascomycete.org 9(4): 124-134.

Boom, P. P. G. van den, Clerc, P. \& Ertz, D. 2015. New records of lichens and lichenicolous fungi from La Gomera (Canary Islands, Spain), including the new species: Usnea boomiana P. Clerc. Candollea 70(2): 165-177. https://doi.org/10.15553/ c2015v702a1

Ertz, D., Diederich, P., Lawrey, J. D., Berger, F., Freebury, C. E., Coppins, B., Gardiennet, A. \& Hafellner, J. 2015. Phylogenetic insights resolve Dacampiaceae (Pleosporales) as polyphyletic: Didymocyrtis (Pleosporales, Phaeosphaeriaceae) with Phoma-like anamorphs resurrected and segregated from Polycoccum (Trypetheliales, Polycoccaceae fam. nov.). Fungal Diversity 74(1): 53-89. https: / / doi.org/10.1007/s13225-015-0345-6

Giralt, M. \& van den Boom, P. P. G. 2011. The genus Buellia s.1. and some additional genera of Physciaceae in the Canary Islands. Nova Hedwigia 92(1-2): 29-55. https://doi.org/10.1127/00295035/2011/0092-0029

Hawksworth, D. L. 1979. Studies in the genus Endococcus (Ascomycotina, Dothideales). Botaniska Notiser 132: 283-290.

Hernández-Padrón, C. E. \& Pérez-Vargas, I. 2010. División Lichenes y Lichenicolous Fungi. - In: Arechavaleta, M., Rodríguez, S., Zurita, N., García, A. (eds): Lista de especies silvestres de Canarias (hongos, plantas y animales terrestres)]. Conse- 
jería de Medio Ambliente y Ordenación Territorial Gobierno de Canarias.

Montelongo, C. G., Hernández Padrón, C. E., Paz, P. L. P. \& Pérez-Vargas, I. 2015. Adiciones a la Biota Liquénica de las Islas Canarias IV. Vieraea 43: 207-217.

Orange, A., James, P. W. \& White, F. J. 2010. Microchemical methods for the identification of lichens. British Lichen Society.

Pérez Vargas, I. \& Pérez-Ortega, S. 2014. A new endemic Ramalina species from the Canary Islands (Ascomycota, Lecanorales). Phytotaxa 159(4): 269-278. https://doi.org/10.11646/ phytotaxa.159.4.3

Pérez Vargas, I., Etayo, J. \& Hernández-Padrón, C. 2013. New species of lichenicolous fungi from the Canary Islands. Phytotaxa 99(2): 58-64. https:/ / doi.org/10.11646/phytotaxa.99.2.2

Pérez Vargas, I., Hernández Padrón, C. E. \& Pérez de Paz, P. L. 2011. Adiciones a la Biota Liquénica de las islas Canarias III. Vieraea 39: 111-120.

Pérez-Vargas, I., Hernández Padrón, C. \& Pérez de Paz, P. L. 2012a. Pertusaria etayoi (lichenized Ascomycota: Pertusariaceae) a new lichen species from the Canary Islands. Lichenologist 44: 333-337. https://doi.org/10.1017/S0024282911000934

Pérez Vargas, I., Hernández-Padrón, C., Pérez de Paz, P. L. \& Elix, J. A. 2010a. Tephromela follmannii (lichenized Ascomycota), a new species from the Canary Islands. Mycotaxon 112: 9-14. https:// doi.org/10.5248/112.9

Pérez-Vargas, I., Hernández-Padrón, C., Arroyo, R. \& Seriña, E. 2010b. Usnea brasiliensis (Zahlbr.) Motyka (Parmeliaceae), a new amphi-Atlantic disjunct lichen species. The Bryologist 113(2): 308-312. https://doi.org/10.1639/0007-2745113.2.308

Pérez-Vargas, I., Hernández-Padrón, C., Arroyo, R. \& Seriñá, E. 2010c. Usnea chaetophora, a lichen new to the Macaronesian Region. Lichenologist 42(3): 347-351. https://doi.org/10.1017/ S0024282909990661

Pérez Vargas, I., Hernández-Padrón, C., Pérez de Paz, P. and Elix, J. A. 2010d. Xanthoparmelia teydea, a new brown Xanthoparmelia (Parmeliaceae) from the Canary Islands. The Bryologist 113(1): 51-54. https://doi.org/10.1639/0007-2745-113.1.51

Pérez-Vargas, I., González-Montelongo, C., Hernández Padrón, C. H. \& de Paz, P. L. P. 2015a. A new species in the lichen genus Caloplaca from the Canary Islands, including a key to all brownblack Caloplaca sensu lato species in Macaronesia. Phytotaxa 205(3): 205-210. https://doi. org/10.11646/phytotaxa.205.3.8

Pérez-Vargas, I., González Montelongo, C., Hernández Padrón, C. \& Pérez-de Paz, P. L. 2015b. Contribution to the knowledge of the genus Cladonia in Macaronesia. Botanica Complutensis 39: 31-35. https://doi.org/10.5209/rev_BOCM.2015. v39.49131

Pérez-Vargas, I., Hernández Padrón, C., Pérez de Paz, P. L. \& Elix, J. 2012b. A new saxicolous species of Diploschistes (Thelotremataceae) from the Canary Islands. Lichenologist 44: 67-71. https://doi. org/10.1017/S0024282911000612

Pérez-Vargas, I., Hernández-Padrón, C., Pérez-de Paz, P. L., van den Boom, P. P. G. \& Jørgensen, P. M. 2014. A new species in the lichen genus Vahliella from the Canary Islands, including a key to Vahliellaceae, Pannariaceae, and Coccocarpiaceae in Macaronesia. Phytotaxa 167(2): 183-188. https://doi.org/10.11646/phytotaxa.167.2.4

Tehler, A., Ertz, D. \& Irestedt, M. 2013. The genus Dirina (Roccellaceae, Arthoniales) revisited. Lichenologist 45(4): 427-476. https://doi.org/10.1017/ S0024282913000121

\section{Errata}

In the paper about Gran Canaria, lichens and lichenicolous fungi (van den Boom 2010: 365), Pterygiopsis hassei Fink is listed (under Zwackhiomyces heppiae). Such name does not exist, so it is a clerical error. The name refers to Psorotichia hassei Fink., identified by Dr. Matthias Schultz, under this correct name.

\section{Reference}

Boom, P. P. G. van den 2010. New or interesting lichens and lichenicolous fungi of Gran Canaria (Canary Islands, Spain). Willdenowia 40(2): 359-367. 
124 Folia Cryptog. Estonica 